\title{
Distance Education as an Object of Study and Reflection of Pedagogy in Poland
}

\author{
Maciej Tanaś
}

\begin{abstract}
The digitization of the media, their software and hardware combination of computers and the development of networks and their dissemination have made distance learning the subject of research, implementation of practical and scientific reflection once again. Those actions are promoted not only by the development of ICT, but also by progressive globalization, demographic changes and economic and cultural challenges. The scientific discourse is also a part of Polish experiences.

The previous treatment of the subject of this paper were historical in nature, fragmentary or were descriptions of individual experiments and experiences of individual universities. Presented approach has not only a synthetic character, but also provides an outline of the original, the Polish concept of teaching - blended learning.
\end{abstract}

Keywords - distance learning development, remote teaching in Poland, MOOC's, blended learning

\section{INTRODUCTION}

$\mathbf{R}$ EGARDLESS of a way of defining culture, either as ,the entire material and spiritual heritage of humanity" [1] or "the degree of excellence, efficiency in mastering and connoisseurship of one specialty" [2], man that creates it needed symbols of thoughts, sounds and images as well as carriers that allow to record them.

This is what was the cause of the first discoveries of numbers, letters and notes and reason to use them to paint them on the cave walls, clay tablets, papyrus and paper cards, and after time the cause of construction of equipment allowing not only to write, but to manipulate words, sounds and moving pictures. Convergence of digital media inside computers and the Internet have done the rest.

\section{DISTANCE EDUCATION AS AN OBJECT OF STUDY AND REFLECTION OF PEDAGOGY IN POLAND}

The history of distance learning is long. Since the dawn of time man invented and built tools to subjugate the nature. These were tools increasing the strength of human muscles but also supporting cognitive processes like perception, memory and thinking, as well as intensifying expressive functions like speaking, writing and reading, and even - construction functions and praxis. The development of distance education, although territorially and thematically diverse, had, however, some points in common. These were on the one hand - another implementations of scientific discoveries in the field of communication technologies and their spread, on the other -

M Tanaś is with the Maria Grzegorzewska Academy of Special Education in Warsaw, e-mail: mctanas@gmail.com the eternal human dream of the possibility of the transmission of knowledge, regardless of time, space and biological limits of the human body, and as well its intergenerational inheritance, more durable than single human life and finally the possibility of sharing knowledge with others and learn from numerous sources without restrictions.

The aim of the article and lack of space make it impossible to provide an overview of the historical development of distance education, also called sometimes from French telematics education, in Poland. However, it seems important to recall two cases: a lack of consensus on the recognition of who, when and how realized first remote courses as well as lack of acceptable and useful classification of this form of education.

Dominating point of view in American literature is that a proof of one of the first attempts to distance learning was information placed in 1728 in the Boston Gazette which looked so "Caleb Philipps, a teacher of the new Short Hand method". The course consisted of weekly lessons sent to its participants. [3]. Others say that the first course conducted by Sir Isaac Pitman in 1840 . He taught shorthand via correspondence through postcards. The method was interactive because its author evaluated and corrected the works sent by students. It is this interaction was a major novelty popular in England courses Pitman.

Others say that the first distant learning course was conducted by Sir Isaac Pitman in 1840 . He taught shorthand via correspondence through postcards. The method was interactive because its author evaluated and corrected the works sent by students. It is this interaction in Pitman's courses which became popular in England which was a major novelty for everyone. [4]

The Polish scientific literature argues [5] that distance learning was launched at the Jagiellonian University in 1776, by realizing correspondence lectures for people from outside the University. Open learning (realized stationary or remotely) became increasingly common. In 1779 in Warsaw, an open lectures on physics were realized. In the eighteenth century, the Society of Academic Courses for Women, later converted into Common Academic Lectures [6] came into existence. In the second half of the nineteenth century (1886) the Flying University was established in Warsaw. It became the most important center of academic life under Russian annexation [7] in the nineties of the nineteenth century. Twenty years later it was transformed into Society of Higher Academic Courses.

It is worth recalling these examples to demonstrate that the process of knowledge sharing at a distance is much older than implemented by the newspaper. Certainly, letter was the primary medium so it is hard to underestimate correspondence 
distance learning (i.e. teaching religion) which used singlesided or double-sided transfer of information through letters.

Distance learning was implemented for centuries. Since the dawn a man shared his knowledge, own thoughts, experiences, ideas, and beliefs. This was done - historically speaking always using the tools available for civilization. The letter was earlier than the press. Certainly, also 13 letters of Paul of Tarsus and one written by someone in his entourage, letters of John the Evangelist, St. Peter the Apostle, James the Apostle and Jude Thaddeus stood ahead of the centuries of learning content published in newspapers. Basic moral precepts dictated by God to Moses, called the Decalogue, the Ten Commandments or the Ten Statements and known from the Book of Exodus and the Book of Deuteronomy, were earlier than the Epistles of St. Paul [8]. Other examples confirming the thesis that the letter was a tool for distance learning can be cited.

Education by correspondence issues became the subject of pedagogical reflection in Poland, mainly thanks to the work of Elzbieta Zawacka [9]. Unfortunately, her studies, projects and researches were not spread, on the contrary they were often depreciated in that politically difficult period. At the same time in the $60 \mathrm{~s}$ and $70 \mathrm{~s}$ of twentieth century there have been significant action taken in the use of mass media in Poland. In the first half of the 60s educational television broadcasts for primary and secondary schools were emitted. In the period of 1966-1971 Television University was established. It was organized by Janusz Tymowski (Government Plenipotentiary for the Television) and Tadeusz Nowacki. Program team counted seven people. A method of television broadcasting combined with correspondence learning was used. It is also worth mentioning that in February 1965 in a three-year National Technical High School of Horticulture in Leszno a Correspondence Education Department was established. Initially, learning there lasted six semesters, then it was extended to seven semesters. While in 1976 the name of the school was changed to Sons of Regiment Agricultural Schools, but in its structure, next to the Technical High School of Horticulture and School of Agriculture, an Extramural Television Agricultural Technical High School was added. [10] It should also be noted that in the years 1974-1990 on Polish Television and Polish Radio lectures for teachers were broadcasted under the Teachers' Radio and Television University (NURT). [11]

In 1990, two Dutchmen, Johannes Huijnk and Gerardus van Hezewijk opened a correspondence school in Poland. On 15th of February in 1991 the District Court in Poznań registered a company called European School of Correspondence Education (ESKK) [12] which started the first English language course the same year. The creator and owner of ESKK is ESCC (European School for Correspondence Courses) - Dutch group which offers education in extramural mode in 7 countries in Central and Eastern Europe (Poland, Hungary, Romania, Russia, Ukraine, Kazakhstan, Belarus).

It is worth recalling that the political changes, the first free parliamentary elections, social and economic change and inclusion of Poland in a system of computer networks and their spread in the $90 \mathrm{~s}$ of the twentieth century has laid the foundations to take a number of initiatives also in the field of distance learning. With little simplification a way of educational uses of computers in the learning process can be described graphically as follows:

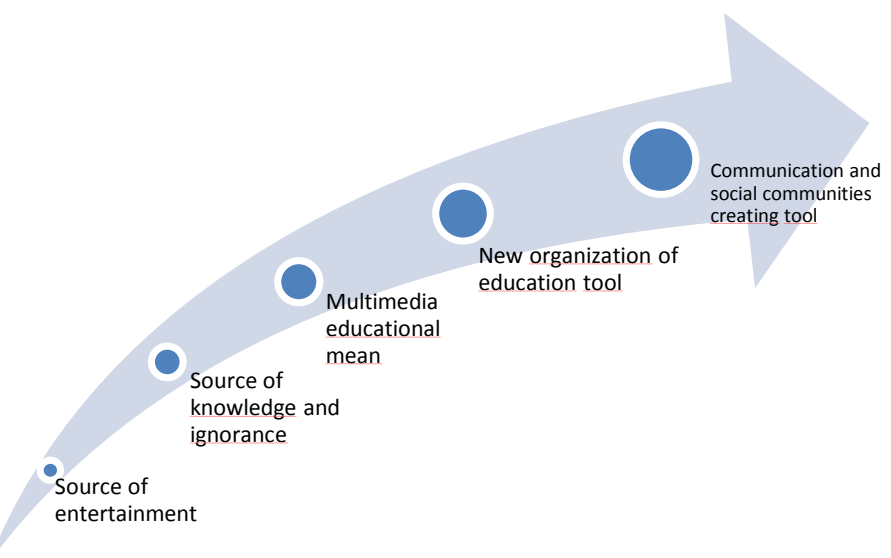

Fig. 1. Information and communication technologies in education

A way outlined above is close to a conceptual approach emerging in Poland on the basis of the theory of teachinglearning, traditionally called overall didactics.

The first initiatives associated with the use of computers in remote teaching appeared relatively quickly. At the same time, however, the first organizational solutions related to remote education were initiated in academia usually by physicists, mathematicians and computer scientists, not by the pedagogues. This was surprising, because in pedagogical sciences programmed teaching concepts developed and promoted in the seventies by Czeslaw Kupisiewicz (block programming creator) and many of his followers, were still alive. [13]

The organization of distance learning via computers in Poland encountered a number of barriers, including:

1. The fears of those who perceived cultural, social and personal risks associated with the implementation of distance learning, or those who saw it as a threat of new forms of domination, as well as those who had a conservative attitude

2. Unsettled legal, economic and organizational aspects (copyright, salaries for teachers conducting distance learning, method of teaching time calculating, competences etc.)

3. Lack of well-trained specialists of that kind of education (postgraduate studies still struggling with a lack of candidates because of non-recognition of such studies as a way of increasing qualification level)

4. Low level of investments in education and pauperization of teachers and pedagogues in Poland

5. Too high costs of hardware, software and Internet connectivity for many years (lasting longer or permanent, and necessary in the case of e-learning), especially for impoverished rural and working-class

6. An inefficient way of using computer labs in schools (almost exclusively during regular classes and possibly on additional classes) and the weakness of the system of permanent modernization of equipment ("School Moodle", a project of Education Development Center is not the norm).

At first it seemed that ways can be found to overcome these obstacles by:

1. Legislative initiatives, and especially allowing to teach information technology (or IT and media education) on pedagogy studies (and not only on the IT Faculties). 
2. The establishment of distance learning teaching standards for the future teachers and pedagogues.

3. Establishment of organizational and economic standards for e-learning and rising the community awareness that promotes distance education.

4. Introducing appropriate education programs (courses, workshops, conferences and other forms) for active teachers and educators.

Unfortunately, despite the passing time, a number of solutions formulated above remain only theory. It still lacks appropriate methodical, organizational and legislative actions. Actions of individual centers are still atomized and usually limited to "education instead." The paradox is that directions of development and educational use of more and more powerful technologies are so poorly controlled. It seems that this was due to a lack of understanding that the latest technologies can become a field of educational innovation. They also allow to pursue another organizational form of distance education, designed to increase the efficiency of the existing system of education.

In this context, the most important acts of distance education undertaken by a few academic centers, should be highlighted. Today, distance education is developed by many academic centers in Poland. The most important are still the ones who first took action to implement distant learning activities for students, as well as those which launched the first complete, remote academic studies:

In 1996 AGH University of Science and Technology in Cracow has established an Extramural Education Centre which was renamed into E-Learning Centre.

In 1999 University of Warsaw has established an interdepartmental Centre of Open Multimedia Education. In 2007 a Polish Scientific Society of Internet Education was founded.

Maria Curie-Skłodowska University in Lublin and High School of Humanistic and Economics in Łódź created Polish Virtual University. First studies were launched in 2002 (management and marketing, computer science) and next in 2003 (political sciences, nursing). First distant learning students graduated in July 2005.

Warsaw University of Technology created Centre for Distance Education, which uses Internet to conduct remote studies from 2000.

Warsaw School of Economics established its distance learning system, which is administrated by Extramural Education Development Centre, in November 2001. E-SGH system allows to conduct classes and lectures and lets students to download additional materials.

In 2005 Jagiellonian University in Cracow has established Distance Learning Centre to promote and coordinate distance education which is conducted on two platforms (BlackBoard and Moodle).

Other academic and educational institutions also implement modern remote education. Extramural Education Centre of Gdansk University of Technology, Remote Education Portal of Wroclaw University of Technology (ePortal), an online educational platform of Regional Centre of Methodology and Education METIS in Katowice are only few examples. Note that most popular in Poland are free of charge platforms, in particular Modular Object-Oriented Dynamic Learning Environment (Moodle).
If we assume that the development of distance learning, related to the need to share knowledge, its distribution and spreading depended on the development of civilization and the realization of the eternal human dream of overcoming the barriers of time and space it shows that distance learning can be classified according to the criterion of the number of media on: single-medial, bi-medial and multi-medial. This is illustrated in the following chart:

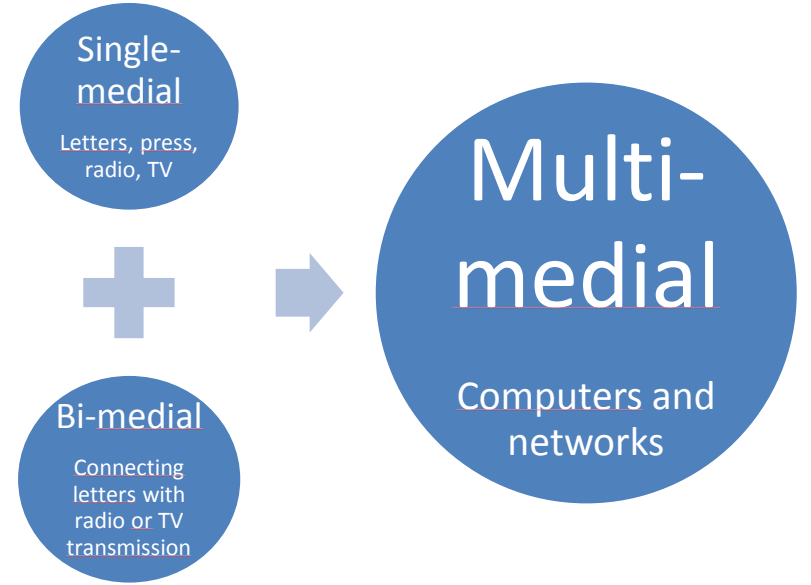

Fig. 2. Remote education - primary and secondary characters

Adopted in the above classification criterion of medium reveals the reasons of the attractiveness of distance learning, which is using the Internet, mobile phone network, PC (personal computer, desktop computer), and increasingly also mobile devices (mobile computing), including wearable computers. The networked computer helped in fact to overcome the barriers of historically earlier forms of distance learning because:

1. It combines the features of many media, allows you to present content using different means of expression and involves many senses the user.

2. It allows to exceed barriers of territorial, temporal and biological nature.

3. It enables the modeling and simulation of phenomena and processes in ways that are impossible to traditional forms of teaching.

4. It is useful for communication.

5. It can be a tool for understanding reality in virtual reality.

Note that the user has a choice and can make a decision on the type of service, range of search, time of use and the type and scope of content that he reaches, processes, stores or transmits. It gives him a subjective sense of decision and creating power, the presence of which educators and teachers are calling for in the process of teaching-learning for years. Distance learning using computer and network at the same time enables the individualization of way and content of education, as well as the time allocated for it. The potential number of recipients, which could greatly exceed the capacity of the classroom and even the largest lecture hall is also significant. [14] In the age of computers and the Internet a word is still a carrier of human knowledge, culture and art, but thanks to the media it broke its limits. Distance learning using a computer connected to the telecommunication network is not just a technology, but a way allowing implementation of the demands that are put forward over the years on the basis of 
pedagogical sub-discipline called overall didactics. It is a new, attractive and fully valued organizational form of education.

Meanwhile, three widely shared positions on distance education carried out using computers and networks can be found in the literature. The first of them is similar to the paradigm of de-schooling, the second - an alternative school, while the third - constantly improved schools. These three paradigms, distinguished by Czeslaw Kupisiewicz [15], can clearly explain the contemporary ways of understanding the role and function of the computer distance learning. Needless to say, that only the acceptance of the paradigm of constantly improved school allow to rationally integrate ICTs (Information and Communication Technologies) into teachers' range of methods and to improve traditional teaching organization thanks to complement it with remote education. Of course ICT is not a panacea for the education ills. However, they may help to overcome the barriers of conventional schooling and higher education and contribute to the system LLL (Lifelong Learning).

Computer and Internet should be considered as useful tools of education both in primary and secondary school and at university level. These are tools to assist management and administration base, easing flexible organization of education, and above all are helpful in the process of education, selfeducation and interpersonal communication. They are also tools that ease the work of library, ease multiplication and distribution of teaching materials. Computers and Internet are introducing a new quality of scientific work. Among the many fields of application possibility of implementing distance learning with the help of a network of mobile and stationary computers, as well as mobile smartphones seems worth scientific and practical use.

Today, traditional teaching in the classroom and the lecture hall is increasingly being enriched by remote education, treated as complementary, completive and specialized. Remote education has become a social fact, despite the resistance of conservative people.

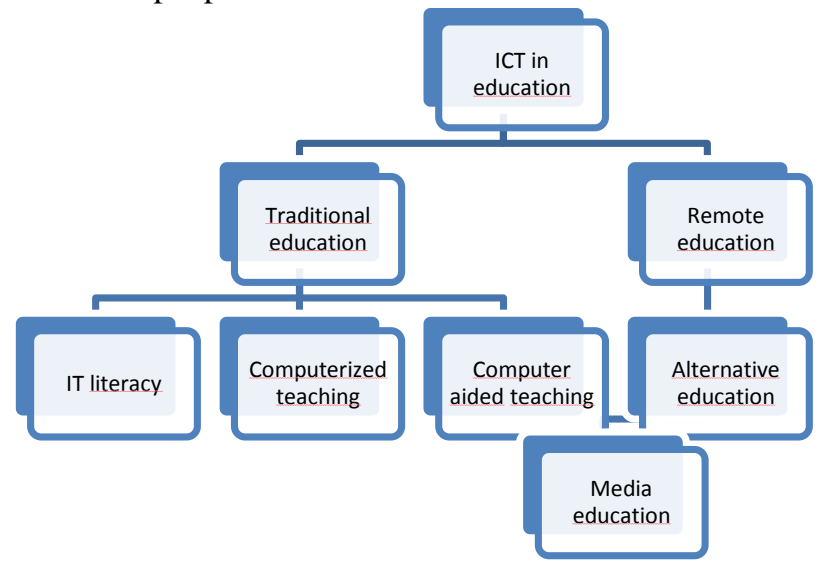

Fig. 3. Fields of research and pedagogical reflection in Poland in terms of information and communication technologies applications of in traditional and remote education process

Computer and network are treated either as substitutes for traditional educating or as a tool to support and ease eliminating some of the drawbacks of traditional education. The first position, characteristic for the early attempts of use of computers in education (called a computerized education them), led astray not bringing the expected results. Naive, not respecting pedagogical knowledge, technocratic approach to the education process must lead to educational failure. Even spontaneously undertaken self-study with computer programs devoid of teacher's essential leadership, led at most to a fragmented, inconsistent and incomplete knowledge. The second position (known as computer or network aided education), accepting a utility function of a computer and the Internet and the prime role of a teacher, brought different, didactically desirable results. Therefore, it has become a field of numerous studies and implementations. In recent years, the concept of blended learning once lined by the author of this paper is gaining more and more supporters in Poland. [16] Implemented, it retains what is most precious in the traditional teaching-learning process with intentional inclusion of methods and tools for distance learning. Blended learning should be implemented taking into account standards or regulations that should be respected by the teacher during undertaken educational processes. These principles and standards adopted in teaching were called principles of education.[17] During the mutual implementation of complementary stationary and remote teaching the registry of principles of education expands. It includes not only those that are useful during the traditional school education, but also those whose observance turns out to be important because of new opportunities, which provides information and communication technology. Principles, that should be included above all in the teachers' work should be:

1. Principle of conscious and independent participation of all participants in the process of teaching-learning;

2. Principle of cooperation of teachers and learners;

3. Principle of individualization and optimization of the process of education;

4. Principle of comprehensive mobilization of the student to use information critically and creatively;

5. Principle of creative, combined and alternate use of different methods and media so that they complement each other;

6. Principle of the efficiency, regularity and effectiveness

These principles of teaching, extracted and defined by J. J. Czarkowski, fit well into the registry of norms and rules of teaching in blended learning. [18] Their knowledge eases the implementation of the teaching-learning process and can make it more effective. Certainly, education process partly transferred to cyberspace must respect not only the technical and information technology rules, but also principles of pedagogy. Only when combined, their inclusion in the planned projects may lead to educational success and economic development. Unfortunately, previous exploration of teaching tasks followed by the presence of the media in many spheres of human activity, including the consequences of the application of remote education, which is implemented using the tools of information and communication technologies and supplementary to the classic mode, is more like a task to perform, than a sufficient source of pedagogical reflection. The issue of directory of educational tasks resulting from the presence of the media in the education process and their axiological and cultural context, the personal and social consequences (and barriers) of the absence or presence of these values in the process of distance learning, the state of taking into account pedagogical values during the remote teachinglearning processes and more remain open and unresolved. The 
problem of the directory of values, their selection and hierarchy raises lively discussions and scientific disputes. It is entangled historically, culturally, religiously and so on.

The Internet has met the immemorial dream of man. Dreams of space which allows crossing the limits of human frailty and fear of death. The space in which the barriers of time and distance vanish. [19] What is needed, however, is a serious analysis of the educational role of digital media. Even if we assume that we have a methodology of using the press, radio and television in the classroom, the features of digital media require a new methodology. Attempts has been made to determine their role using traditional categories, but they do not work. Of course, the tools of information technology are not carriers of those values that constitute the pedagogical sense of use of computers in teaching. It was rightly pointed out years ago by Wladyslaw Zaczyński. In his opinion, "the meaning / ... / it is not inside the technological values, but in ethical and cognitive values". IT tools undoubtedly have advantages, but they are neither a panacea for the ills of education, nor a new, cheaper, controllable and vulnerable to manipulation replacement of the teacher. However, like any tool which is used by man, they allow to improve or fix something, they are more or less useful than other measures. They also leave its mark on the user. Sometimes this mark is didactically undesirable or even personally, socially or culturally dangerous.

The purpose of education is to form people capable of creating new things, creative and revealing, but not more or less capable of copying others or only efficient workers. In a situation where polish school is more often and more insistently encouraged to give up educating of independent and creative minds capable of critical thinking and validating data, not accepting everything that was suggested to them - the Internet space creates the chance for activation of children and young people, their stimulating, but also shaping. On the other hand, in polish school pupils are gaining knowledge of the history of art, history, literature, history of music, but they are taught how to paint, sculpt, write poetry or play musical instruments. These practical, but how valuable skills can be, without doubt, widely developed using a computer network, cell phones, digital cameras and cameras, tablets and so on.

Pedagogy is facing a serious challenge. The reform of the education system in Poland that started not so long ago has not predicted the right place for media education neither in the education of educators and teachers, nor in teaching youth.

Area and number of scientific and research fields of information and communication technologies and their users in the aspects of pedagogical interests is growing. It is worth recalling that these researches over the years were arranged in a certain continuum: from computer literacy issues by identifying various fields of computers and the Internet in education and an analysis of the historical development of distance learning, its models, teaching values etc., until the construction of basics of media education.

Pedagogical reflection on digital media was created at the junction of many ideas: didactic, informatics, technological, cultural studies, media studies, anthropology and cognitive. Preliminary determination of educational research fields of computing and language construction has led to a methodological reflection, building the basics of a new subdiscipline of teaching, called the pedagogy of media or media

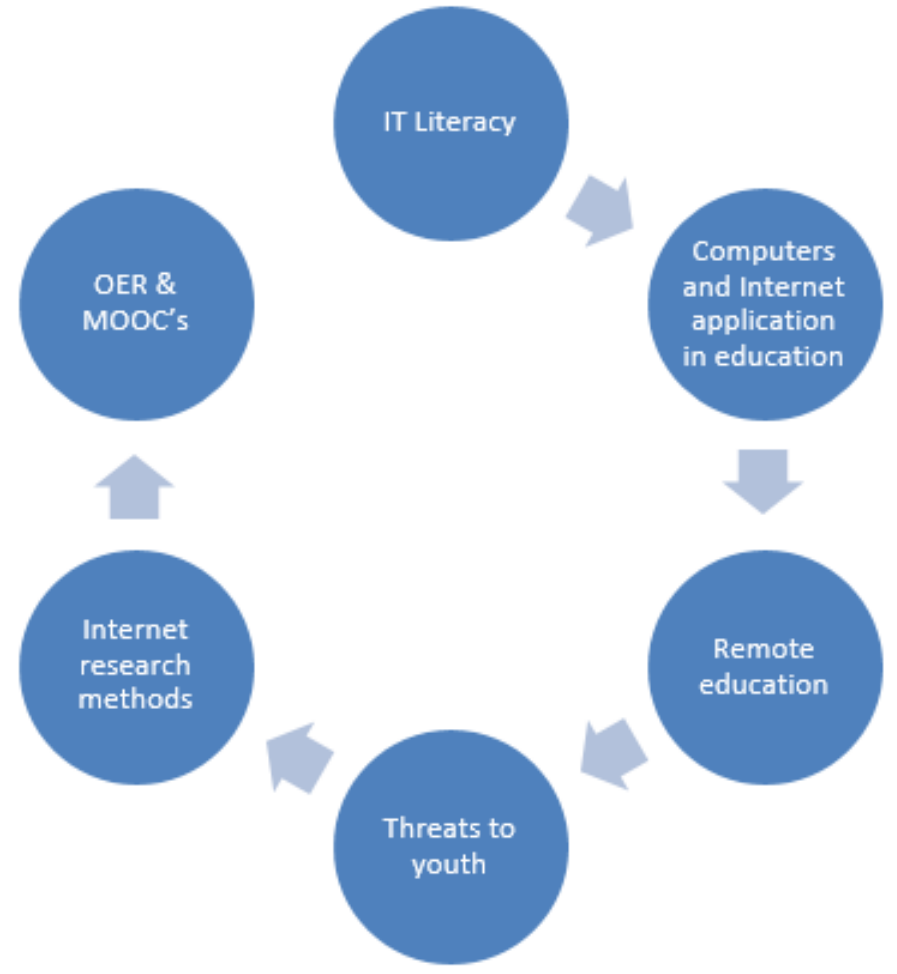

Fig. 4. Media education research fields in Poland in historical perspective

education. Because of the varying age of respondents - it is advocated to change its name to antropoandragogy of media, which is a scientific reflection on the functioning of the human in the environment of media in all stages of its life and development.

As a result of the qualitative development of ICT and digital media spreading there are additional, new fields of research. Two of these areas, OER and MOOC's, require extensive comment.

The term OER, which is an acronym for Open Educational Resources, covers all educational resources for which there is a fully open access thanks to their free licenses or transfer to the public domain and set available with any of ICTs. The name probably came into being at a meeting of UNESCO in Paris in 2002, where the participants expressed a desire "to create together a universal educational resource available for the whole of humanity and hope that this open source of knowledge will mobilize the whole of the worldwide community of teachers in the future". Open Educational Resources are defined differently. [20] The idea remains the same - to build a common space and resources of human knowledge, art and culture.

An example of OER resources created around the world is a project of Massachusetts Institute of Technology called MIT OpenCourseWare.[21] It is an educational program lasting for more than 10 years, under which MIT publishes for free almost all of its materials. Currently, OpenCourseWare contains 2150 courses, which have benefited more than 125 million people till this day. According to Dick K. P. Yue the objective of the project is clear: "to publish all of our materials on the Web and make them widely available to everyone." [22]

Also in Poland there are number of measures undertook to share library resources and other materials for teaching or research. Examples are projects created within the framework of the Foundation of Modern Poland (founding member of 
Coalition for Open Education founded in 2008), aimed at helping children in learning and using of information technology. Another option is a repository of open educational resources Open $\mathrm{AGH}$, or activity provided by the Digital Libraries Federation which have already shared 1526612 publications. [23] Number of resources increases, so does awareness of their usefulness and the social, cultural and economic role.

In May of 2012 Massachusetts Institute of Technology and Harvard University have started a joint project called EdX. [24] The goal was the implementation of online university courses across a range of disciplines for students from all over the world without charges and also conducting research about the learning process. This consortium, made up by 29 universities and colleges, is one of the most prestigious in the world. The first prototype course "Circuits and Electronics" started in December 2011. EdX has now already 1.2 million users. EdX also inspired a number of educationally important programs like Khan Academy or Carnegie Mellon University's Open Learning Initiative.

Several entities had launches projects like MOOC's (Massive Open Online Courses). Alison company founded in 2007 by Mike Feerick'a,[25] as well as Udacity (at that time KnowLabs),[26] which was founded by David Stavens and Sebastian Thrun (first course "Introduction into AI" took place in autumn 2011) [27] and Coursera - founded by professors at Stanford University: Andrew Ng and Daphne Koller, and launched in 2012 by Stanford University, Princeton, the University of Michigan and the University of Pennsylvania [28] were those, who played the pioneering role. 12 consecutive universities joined the program in July 2012, 17 in September 2012. In February 2013 [29] they informed about the next 29 universities, and in May 83 academic centers participated in the project. [30] Their number continues to increase, and the initiative includes esteemed universities all over the world and has a global reach.

On September 8, 2013 academic universities from UK [31] realizing the project The Open University under the name "FutureLearn" had joined the race for space the Internet and the global marketplace. In June 2014 the project has already involved 36 universities and non-academic institutions like the British Museum, the British Council and the British Library. The number of research and teaching centers undertaking collaboration continues to grow.

In the years 2012-2014 in Europe there were other initiatives of mass distance education also taken. And so in February 2012 former employees of Nokia in Finland launched Eliademy.com [32] based on the Open Source Moodle Virtual Learning Environment. [33] The site is located in more than 19 languages (including Latin) and was designed for mobile use. [34] In March 15, 2012, Jorge Ramió and Alfonso Muñoz of the Universidad Politécnica in Madrid launched Crypt4you Spanish kind of MOOC. Iversity is a provider of Mooc in Germany [35] and the biggest MOOC in Europe so far (more than 82,000 students in November 2013). [36] On the other hand OpenupEd [37] is a transnational platform, founded with the support of the European Union. In Ireland, ALISON made possible to achieve free certificates through online for several million students from all over the world. [38] In October 2013, the French Government announced the creation of Universite France Numérique), as an alternative to existing solutions.
French business schools have launched their own MOOC's type projects. First of them was supervised by Alberto Alemanno. [39] Finally, in February 2014, the University of Rijeka initiated the project Ricount of MOOC's in the Croatian language. [40]

The development of OER and attempts by the world's major research centers initiatives such as: EdX, Coursera or UDACITY recently observed make the issue of public, multisensory, interactive and distance learning has become one of the most important educational challenges of our time. Development MOOC's motion which is the first one of this type in the history of education, raises the need to re-reflect on the social role of schools, the teaching profession, cultural determinants of education and its importance for the development of the information society. Certainly common distance learning (MOOC's) not only had revolutionized traditional models of formal education, but also opened up an elite Ivy League for those who, because of economic and geographical reasons, could not dream of taking part in education that was led in elite universities.

Global knowledge and memory are becoming a fertile field of digital didactics, once again defining the aims of education in amended by ICT school reality, socially and culturally wider. Didactics is seeking for new ways of selection of education material, new organizational forms, methods of individual, group and mass education, methods of diagnosis and assessment of student achievements. It is also taking up the study of objectives and content of education and training and the conditions of teaching in cyberspace. Didactics is also aimed at training human harmoniously developed in the cognitive, emotional and volitional and psychomotor way. That education, understood as introduction to valuable life, is carried out with respect for the principles of lifelong learning, recognition of the role of master and teacher in direct education, but also recognizing the growing importance of digital technology.

Thanks to the development and spread of ICT tools the media space with unstable and dynamic culture has grown. It is accompanied by a scientific reflection, born of science education, called the pedagogy of media or media education. Its sources can be traced in the works of Ludwik Bandura [41], Waclaw Strykowski [42], Wladyslaw Zaczyński, Janusz Gajda, Bronislaw Siemieniecki, Stanislaw Juszczyk, Marek Furmanek and Wielisława Osmanska-Furmanek, Janusz Morbitzer, Jan Łaszczyk, Stanislaw Kwiatkowski, Kazimierz Wenta, Waldemar Furmanek, Barbara Kędzierska, Jozef Bednarek and many other educators. The number of people who study the educational use of computers, including distance learning, grows in Poland. There is a growing scientific status of media education.

\section{ENDING}

Convergence of media, that has been made in computer software and hardware meant that they have become extremely attractive tools. They are in fact the realization of the eternal human dream of writing numbers, words, sounds, images, color and movement and making them more permanent than the lives of their creators and users. At the same time, building a network connecting computers and users, allowed us to create an interactive space in which people can cross 
biological, temporal and territorial boundaries. This probably is the reason of the attractiveness of first computers, mobile phones and the Internet, more broadly - multimedia information and communication technologies and their gear.

\section{REFERENCES}

[1] B. Suchodolski, „Kultura” in Wielka Encyklopedia PWN, tome 6, Warszawa: PWN, 1965

[2] W. Doroszewski (Edit.) "Słownik języka polskiego," Warszawa: PWN, 1996.

[3] B. Holmberg, "The evolution, principles and practices of distance education," Oldenburg: BIS-Verlag der Carl von Ossietzky Universität Oldenburg, 2005. p. 13.

[4] M.Tracey, R. Richey "The Evolution of Distance Education," in Distance learning... A magazine for leaders, vol. 2, number 6, p. 18, 2005

[5] J. J. Czarkowski, „E-learning dla dorosłych,” Warszawa: Diffin, 2012, pp. 60.

[6] J. Suchmiel „Działalność naukowa kobiet w Uniwersytecie we Lwowie do roku 1939," Częstochowa: Wydawnictwo WSP, 2000, pp. 44-46.

[7] R. Terlecki, „Uniwersytet Latajacy i Towarzystwo Kursów Naukowych 1977-1981,” Kraków-Rzeszów: Instytut Europejskich Studiów Społecznych, 2000, pp. 14.

[8] M. Tanaś „Kształcenie komplementarne na poziomie akademickim kontekst dydaktyczny i informatyczny," Heteroglossia - Studia Kulturoznawczo-Filologiczne, vol. 1, pp. 95-106, 2011.

[9] E. Zawacka, „Kształcenie korespondencyjne,” Warszawa: PWN, 1967; E. Zawacka „Kształcenie zdalne,” Torun: author's edition 2005, A. Frąckowiak, J. Półturzycki, H. Solarczyk-Szwec (Edit.) „E. Zawacka. Pisma pedagogiczne," Radom: Wyd. Naukowe ITE, 2009.

[10] K. Karauda „Historia w perspektywie edukacji zdalnej (distance learning'u - DL)," Kultura i Historia, vol. 1, 2001.

[11] Nauczycielski Uniwersytet Radiowo-Telewizyjny. Instytut Kształcenia Nauczycieli i Badań Oświatowych. Katowice 1974.

[12] K. Karauda „Historia w perspektywie edukacji zdalnej...” op. cit

[13] Cz. Kupisiewicz „Nauczanie programowane,” Warszawa: PZWS, 1966; Cz. Kupisiewicz „Nauczanie programowane w praktyce szkoły podstawowej,” Warszawa: PZWS, 1971; Cz. Kupisiewicz „Nauczanie programowane w szkolnictwie wyższym," Warszawa: PWN, 1973; K. Kruszewski „Nauczanie programowane w systemie dydaktycznym," Warszawa: PWN, 1974; K. Denek (Edit.) „Programowanie dydaktyczne w szkole wyższej," Warszawa: PWN, 1984.

[14] J. J. Czarkowski „Kształcenie komplementarne człowieka dorosłego,” Rocznik Andragogiczny, s. 184, 2009.

[15] Cz. Kupisiewicz „Paradygmaty i wizje reform oświatowych,” Warszawa: PWN, 1985.

[16] J. Mischke, A. Stanisławska „B-learning: kształcić komplementarnie, co z tego wynika i co się z tym łączy?,” Akademia on-line, Łódź, s. 7, 2006 J. J. Czarkowski „E-learning dla dorosłych...,” op. cit., pp. 225; M Tanaś „Kształcenie komplementarne na poziomie akademickim...,” op. cit,; M. Tanaś „Edukacyjne zastosowania komputerów,” Warszawa: Wydawnictwo Żak, 1997, pp. 127-138.

[17] K. Sośnicki „Dydaktyka ogólna,” Toruń: Wyd. UMK, 1948, pp. 211212; W. Okoń „Wprowadzenie do dydaktyki ogólnej, Warszawa: Wydawnictwo Żak, 1966, pp. 167
[18] J. J. Czarkowski „E-learning dla dorosłych ...,” op. cit.; pp. 227-233.

[19] M. Tanaś „Prolegomena do pedagogiki medialnej. Cyfrowa przestrzen kształcenia," in Cyberprzestrzeń - Człowiek - Edukacja. Tom 1, .M Tanaś, S. Galanciak (Edit.) Kraków: Oficyna Wydawnicza „Impuls”, 2015

[20] "Open Educational Resources". The William and Flora Hewlett Foundation, 27.03.2013; "Giving Knowledge for Free: The Emergence of Open Educational Resources". Center for Educational Research and Innovation, 28.03.2013; White House cites MITx MOOC as key tool for bringing innovations to market more effectively. MIT OpenCourseWare Press Release, June 24, 2013

[21] http://ocw.mit.edu/ [27.03.2013]

[22] http://ocw.mit.edu/about/ [27.03.2013]

[23] http://fbc.pionier.net.pl/owoc, [7.10.2013]

[24] https://www.edx.org/ [27.03.2013]

[25] E. Booker "Early MOOC Takes A Different Path", UBM Tech: Information Week — Education, 2013 [16.07.2013]

[26] http://knowlabs.com/ [16.07.2013]

[27] R. Pérez-Peña "Top universities test the online appeal on free," NewYork: The New York Times, 11.07.2012 [18.07.2012]

[28] "UK university joins US online partnership" BBC News, July 17, 2012, 17.07.2012.

[29] "Coursera adds 29 new universities to bring total to 62 , offers first courses in Chinese, Italian, and Spanish,” The Next Web, 21.02.2013.

[30] "Partner universities," Coursera [31.05.2013]

[31] "UK enters global online university race." BBC News, 8.09.2013; "U.K. MOOCs Alliance, Futurelearn, Adds Five More Universities And The British Library - Now Backed By 18 Partners," TechCrunch 19.02.2013, [30.05.2013]; C. Shaw "FutureLearn is UK's chance to 'fight back', says OU vice-chancellor," The Guardian, 20.12.2012, [30.05.2013]

[32] http://www.Eliademy.com. "Hasso-Plattner-Institut bietet kostenlose Informatikkurse im Netz an," Zeit Online 31.07.2012, [17.03.2015]

[33] "MeeGo To MOOCs, Ex-Nokians Launch Eliademy To Put Education In The Cloud," TechCrunch, 12.03.2013, [13.10.2013]

[34] "Another Look at Eliademy, A cloud-based alternative to Moodle," Moodle News, 2.08.2012; J. Kurhila "Experiences from running a programming MOOC in " Finland," http://www.aalto.fi/en/current/events/ digi_breakfast_on-elearning and moocs/, [27.08.2014]

[35] T. Lewin "Universities Abroad Join Partnerships on the Web" The New York Times, 20.02.2013, [ 21.02.2013]

[36] S. Grossman "American MOOC Providers Face International Competition," The Chronicle of Higher Education, 5.07.2013, [8.07.2013]

[37] www.openuped.eu [27.03.2013]

[38] http://alison.com/learner-and-graduate-survey-results [27.03.2013]

[39] "Alberto Alemano teaches popular online course on EU," NYU LAW, 21.02.2014, http://www.law.nyu.edu/news/Alberto-Alemanno-MOOC, [22.04.2014]

[40] www.ricount.uniri.hr [27.03.2013]

[41] L. Bandura „Pedagogika medialna,” Ruch Pedagogiczny, vol. 3-4, 1983

[42] W. Strykowski „Pedagogika i edukacja medialna w społeczeństwie informacyjnym" in Edukacja medialna w społeczeństwie informacyjnym. S. Juszczyk (Edit.) Toruń: Wyd. Adam Marszałek, 2002, pp. 13-24; W. Strykowski (Edit.) „Media a edukacja,” Poznań: Wyd. eMPI2, 1997. 